\title{
Patients' Views on Self-Management of Chronic Musculoskeletal Pain
}

\author{
Barbka Huzjan* \\ University medical centre of Ljubljana, Zaloška cesta 002, 1000 Ljubljana, Slovenia \\ barbka.huzjan@kclj.si \\ Ivana Hrvatin \\ Faculty of health sciences, University of Ljubljana, Zdravstvena pot 5, 1000 Ljubljana, \\ Slovenia \\ ivana.hrvatin@gmail.com
}

\begin{abstract}
:
Research Question (RQ): Chronic musculoskeletal pain is a complex condition and one of the most important causes of suffering of modern times. Self-management refers to the individual's ability to manage the symptoms, treatment, physical and psychosocial consequences and life style changes inherent in living with a chronic condition. The research question is; what is the view on the selfmanagement of chronic musculoskeletal pain from the patient's perspective?

Purpose: The purpose of this literature review was to review original articles that reported how selfmanagement educational programmes are viewed from the patient's perspective.

Method: We used an integrative review of the literature. The search was conducted from November 2019 to March 2020 on the PubMed, PEDro and OTseeker databases. We included original studies, written in English that examined the patients' point of view on self-management. The included studies, needed to be conducted on adult patients of both sexes, that were suffering from chronic pain and were educated on self-management of their pain. Two authors independently searched for original studies.

Results: Nine article were included in the review. Most of the studies included a multidisciplinary approach. Patients reported they more frequently used passive strategies to manage their pain. They want to be included in the management and be able to communicate with the provider of selfmanagement. There are several positive aspects of a multidisciplinary and groups approach.

Organization: Health care providers can encourage an individual to proactively behave through ongoing processes of communication, partnerships and the creation of appropriate self-management plans over time.

Society: We assume that the analysis will help to identify the social responsibility of the individual and society in the common concern for the health of the population and the individual within it.

Originality: The research provides an up-to-date, new overview of the patients' perspective on self management on chronic pain. The review can be helpful to health care providers s they can compare their expectations with patients's.

Limitations / further research: Further research would focus on high quality studies, and specific forms of multidisciplinary approach, and finding what patients use at a home setting and how to help them continue in the self management of their pain. Limitations of this review include the lack of risk of bias assessment and the fact that this is not a systematic review.
\end{abstract}

Keywords: chronic pain, musculoskeletal pain, self-management, patient perspective, patient experience. 


\section{Introduction}

According to the International classification of diseases chronic pain is a persistent or recurrent pain lasting longer than 3 months. Causes of chronic pain are primary pain, cancer, postsurgical or posttraumatic pain, neuropathic pain, headache, orofacial pain, visceral pain or musculoskeletal pain (Treede et al., 2015, p. 1004). Chronic conditions will be the major cause of death and disability globally by 2020 according to WHO estimates, and by then will account for two thirds of the global burden of disease (Epping-Jordan et al., 2001, p. 947). Population surveys have revealed that chronic pain and its associated problems affect between 10 and 30 $\%$ of the population (Nicholas \& Blyth, 2016, p. 76). In a large-scale survey of the prevalence, severity, treatment and impact of chronic pain in 15 European countries and Israel, $19 \%$ of respondents reported having chronic pain . Of the respondents with chronic pain, $66 \%$ reported having moderate and $34 \%$ severe pain. Twenty-one percent of patients were diagnosed with depression because of their pain, yet only $2 \%$ were currently treated by a pain management specialist. Forty percent of chronic pain sufferers had inadequate management of their pain. Chronic pain seriously affected their social and professional lives (Breivik et al., 2006, p. 288).

Numerous policy and guideline publications have concluded that in order to reduce chronic pain at both the individual and population level, individuals will have to play a central role in the management of their pain (Nicholas \& Blyth, 2016, p. 75). According to previous research patients find it difficult to cope with their pain and its consequences that affect their daily lives (Franklin, Smith, \& Fowler, 2016, p.1). This is generally what is meant by the term "self management".

The purpose of this literature review was to establish current knowledge on how selfmanagement educational programmes are viewed from the patient's perspective. We set out to determine what self-management tools are deemed effective, how a self-management educational programme should be constructed and which health care providers play a significant role from the patients' perspective and whether proposed self-management interventions are consistent with the patient's perspectives.

\section{Theoretical framework}

Self-management refers to the individual's ability to manage the symptoms, treatment, physical and psychosocial consequences and life style changes inherent in living with a chronic condition. Efficacious self-management includes the ability to monitor one's condition and to effects cognitive, behavioural and emotional responses necessary to maintain a satisfactory quality of life (Barlow et al., 2002, p. 178).

Self-management is a key treatment modality for patients with chronic pain (Lukewich et al., 2015 , p. 2552). Consideration is given on how to improve the quality of life of patients with chronic pain through self-management. Self-management of chronic pain should confront patients with the effects of symptoms, treatment, and the psychosocial consequences of a long- 
term condition. There are several possible mechanisms to facilitate self-management, including patient-clinic interaction in routine consultations. This requires patients to be involved in their healthcare, and healthcare professionals are specifically encouraged to develop a patient perspective (Dures et al., 2016a, p.1).

Self-management includes tasks and techniques on having the confidence to deal with medical management and emotional management as well as having a role in the management of their conditions. Self-management of chronic pain is mainly provided in the context of primary care. The delivery of self-management support for individuals with chronic pain has recently been identified as a priority for health care providers (Lukewich et al., 2015, p. 2552). Some examples of pain self-management strategies include activity pacing, problem solving, attention diversion, exercise, goal setting, relaxation, self-monitoring, sleep management, assertiveness and communication skills, deliberate exposure to pain and thought management (Nicholas \& Blyth, 2016, p. 76).

Previous research has focused on primary care, specific conditions or diseases that cause chronic pain. Such information is needed for the prevention and management of chronic pain. Information about the course of chronic pain in the community and factors predicting its onset recovery needed for the prevention and management of chronic pain (Elliott et al., 2002, p. 299). Educational needs are related to knowledge and control of the disease, side effects of treatment and appropriate risk factors, non-pharmacological treatment, pain control, exercise, and behavioural changes. Patient education is not just about transferring knowledge. Evaluating the patient's educational needs are related to knowledge and control of the disease, side effects of knowledge of the educational process is part of evaluating the success of educational interventions (Beauvais et al., 2019, p. 747).

The situation of patients facing with chronic musculoskeletal pain makesthis study very needed, as it helps to find guidelines for maintaining the quality of life of the individual and their family, reducing the cost of health care and maintaining a healthy society. Self-management of chronic pain is a key factor relating to an individual's ability to manage symptoms, treatment, physical and psychosocial consequences, and lifestyle changes associated with living with a chronic condition. We decided to formulate a research question, what is the view of self-management of chronic musculoskeletal pain from the patient's point of view.

\section{Method}

A review of the scientific and professional literature in connection with the studied topic was used in the research. The review of the literature presented is based on a research analysis, using the approach described by Cronin et al. (2008, p. 38). The approach includes formulating a research question, setting criteria for inclusion and exclusion criteria, selecting appropriate literature, assessing the quality of the literature involved, analyzing and synthesizing key findings. We carried out an integrative literature review. The search strategy used was to conduct a bibliographic study of published articles in the following databases PEDro, PubMed and 
OTseeker. The search was conducted using the following keywords: chronic pain, selfmanagement and patient perspective.

The literature search was conducted from November 2019 to March 2020. We included original studies, written in English that examined the patients point of view on self-management. The included studies, needed to be conducted on adult patients of both sexes, that were suffering from chronic pain and were educated on self-management of their pain. Two authors independently searched for original studies. If studies met the inclusion criteria on title and abstract, full text eligibility was assessed. Both authors met and discussed on the full text eligibility of the studies. We excluded articled conducted on patients in palliative care, patients with chronic pain that was not caused by a musculoskeletal condition. We also excluded studies conducted on pregnant women and patients with psychological conditions.

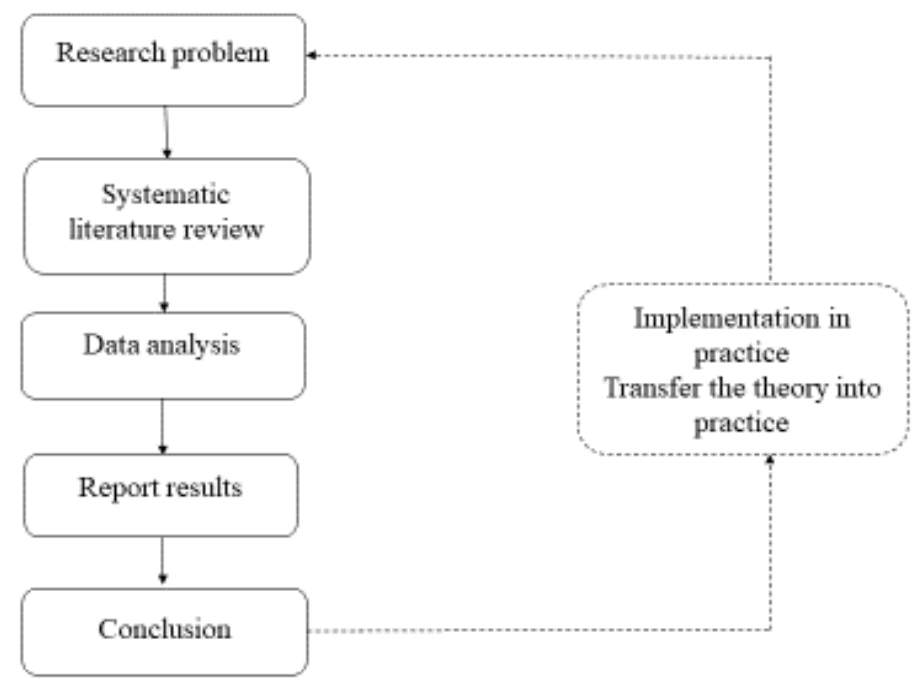

Figure 1: Research model

\section{Results}

We identified a total of 176 publications (PEDro 5, PubMed 126, OTseeker 45). The review included database searches, adequacy reviews and study quality assessments. After analysis, 167 studies were excluded because they did not meet the inclusion criteria or were duplicated. Finally, 9 studies were included in the review (with Journal Citation Reports from 1.7 to 12.3).

In two articles a telephone survey was conducted with the aim to determine what form of selfmanagement patients with chronic pain used at home (Blyth et al., 2005, pp. 285-292; Lukewich et al., 2015, pp. 2551-2562). Blyth and colleagues (2005, p. 285) included 474 adults with chronic pain and asked them to nominate up to 5 strategies that they use to manage their pain. The self-management strategies were grouped in active and passive strategies. Lukewich and 
colleagues (2015) included 239 adults suffering from chronic pain from back problems, osteoarthritis, arthritis, migraines or nerve damage. In both articles passive strategies were more frequently reported to manage chronic pain, in $59.3 \%$ (Blyth et al., 2005, p. 285) and $39.2 \%$ of adults (Lukewich et al., 2015, p. 2555). Of the passive strategies, rest was the most commonly reported (31.5\%), followed by hot/cold pack (23.4\%) and massage (18\%). Exercise was the most common active strategy to manage chronic pain, used in $25.8 \%$ of the included adults, followed by posture correction $(12.1 \%)$. Taking medication was reported in $47 \%$ of the included adults to manage chronic pain. All of the other strategies were reported to be used by less than $10 \%$ of the included adults (Blyth et al., 2005, p. 285). In seven studies the selfmanagement of chronic pain was assessed after a programme was administered to the chronic pain patients. The methodological properties are described in Table 1.

Table 1. The methodological properties

\begin{tabular}{|c|c|c|c|c|c|}
\hline Authors & $\begin{array}{l}\text { Jourlal } \\
\text { Citation } \\
\text { Report }\end{array}$ & Code & Participants & $\begin{array}{l}\text { Self } \\
\text { management }\end{array}$ & $\begin{array}{l}\text { Medical } \\
\text { proffessionals }\end{array}$ \\
\hline $\begin{array}{l}\text { Matthias et al. } \\
2012\end{array}$ & 2,4 & article & $\begin{array}{l}26(4 \mathrm{~F}, 22 \mathrm{M}) \\
40 \text { years }(24-62) \\
\text { chronic } \\
\text { musculoskeletal } \\
\text { pain }\end{array}$ & $\begin{array}{l}\text { physical activity, } \\
\text { accountability, } \\
\text { motivation and } \\
\text { support }\end{array}$ & $\begin{array}{l}\text { nurse care } \\
\text { manager, } \\
\text { clinical } \\
\text { psychologist }\end{array}$ \\
\hline $\begin{array}{l}\text { Franklin et al., } \\
2015\end{array}$ & 1,9 & $\begin{array}{l}\text { research } \\
\text { article }\end{array}$ & $\begin{array}{l}8(6 \mathrm{~W}, 2 \mathrm{M}) \\
53.8 \text { years } \\
\text { chronic } \\
\text { musculoskeletal } \\
\text { pain }\end{array}$ & $\begin{array}{l}\text { cognitive } \\
\text { behavioral } \\
\text { therapy, } \\
\text { mindfulness } \\
\text { based stress } \\
\text { reduction, } \\
\text { acceptance and } \\
\text { commitment } \\
\text { therapy }\end{array}$ & $\begin{array}{l}\text { psychologist, } \\
\text { physiotherapist, } \\
\text { nurse, doctor, } \\
\text { occupational } \\
\text { therapist }\end{array}$ \\
\hline $\begin{array}{l}\text { Bunzil et al., } \\
2016\end{array}$ & 12,3 & $\begin{array}{l}\text { qualitative } \\
\text { study }\end{array}$ & $\begin{array}{l}14(8 \mathrm{~W}, 6 \mathrm{M}) \\
42 \text { years } \\
\text { low back pain }\end{array}$ & $\begin{array}{l}\text { pain education, } \\
\text { posture and } \\
\text { movement } \\
\text { retraining, } \\
\text { functional } \\
\text { integration, } \\
\text { physical activity } \\
\text { and lifestyle } \\
\text { training }\end{array}$ & physiotherapist \\
\hline $\begin{array}{l}\text { Dures et al., } \\
2016 a\end{array}$ & 12,8 & $\begin{array}{l}\text { extended } \\
\text { repott }\end{array}$ & $\begin{array}{l}1210 \quad(895 \mathrm{~W}, \\
315 \mathrm{M}) \\
59 \text { years } \\
\text { inflammatory } \\
\text { arthritis }\end{array}$ & $\begin{array}{l}\text { pain } \\
\text { management, } \\
\text { occupational } \\
\text { therapy, support } \\
\text { groups, patient } \\
\text { education, } \\
\text { psychology and } \\
\text { counseling }\end{array}$ & $\begin{array}{l}\text { doctors, nurses, } \\
\text { occupational } \\
\text { therapist, } \\
\text { physiotherapist }\end{array}$ \\
\hline
\end{tabular}




\begin{tabular}{|c|c|c|c|c|c|}
\hline & \multirow[b]{2}{*}{$\begin{array}{l}19(14 \mathrm{~W}, 5 \mathrm{M}) \\
55(27-75) \text { years } \\
\text { inflammatory } \\
\text { arthritis }\end{array}$} & \multirow[b]{2}{*}{$\begin{array}{l}\text { pharmacological } \\
\text { education, pain } \\
\text { reduction } \\
\text { education, } \\
\text { physical activity }\end{array}$} & \multirow[b]{2}{*}{$\begin{array}{l}\text { physician, nurse, } \\
\text { occupation } \\
\text { therapist, } \\
\text { physiotherapist }\end{array}$} \\
\hline $\begin{array}{l}\text { Dontinued" } \\
\text { Dures et al., } \\
2016 b\end{array}$ & 1,7 & $\begin{array}{l}\text { research } \\
\text { article }\end{array}$ & & & \\
\hline $\begin{array}{l}\text { Hapidou et } \\
\text { al., } 2016\end{array}$ & $\begin{array}{l}\text { no } \\
\text { information }\end{array}$ & $\begin{array}{l}\text { original } \\
\text { research }\end{array}$ & $\begin{array}{l}50(26 \mathrm{~W}, 24 \mathrm{M}) \\
43.96(21-79) \\
\text { years } \\
\text { Chronic } \\
\text { musculoskeletal } \\
\text { pain }\end{array}$ & $\begin{array}{l}\text { relaxation } \\
\text { classes, } \\
\text { functional } \\
\text { activity, exercise, } \\
\text { group therapy }\end{array}$ & $\begin{array}{l}\text { physician, } \\
\text { psychologist, } \\
\text { psychometrist, } \\
\text { physiotherapist, } \\
\text { pharmacist, } \\
\text { social worker, } \\
\text { occupational } \\
\text { therapist }\end{array}$ \\
\hline $\begin{array}{l}\text { Nees et al., } \\
2020\end{array}$ & 5,5 & $\begin{array}{l}\text { original } \\
\text { article }\end{array}$ & $\begin{array}{l}276 \quad(157 \mathrm{~W}, \\
119 \mathrm{M}) \\
44.5 \text { years } \\
\text { Chronic low back } \\
\text { pain }\end{array}$ & $\begin{array}{l}\text { physiotherapy, } \\
\text { aquatic therapy, } \\
\text { medical training } \\
\text { therapy, } \\
\text { biofeedback } \\
\text { training, back } \\
\text { education, } \\
\text { relaxation } \\
\text { therapy, music } \\
\text { therapy, } \\
\text { psychological } \\
\text { pain therapy, } \\
\text { medical } \\
\text { supervision }\end{array}$ & $\begin{array}{l}\text { physiotherapist, } \\
\text { aquatic therapist, } \\
\text { psychologist, } \\
\text { attending } \\
\text { physician }\end{array}$ \\
\hline
\end{tabular}

Legend: $\mathrm{W}$ - female, $\mathrm{M}$ - men.

\section{Role of health care providers}

Lukewich and colleagues (2015, p. 2557) indicated facilitators and barriers of self-management reported by the individuals with chronic pain. The most common reported facilitator was confidence in self-management $(65.3 \%)$, relationship with provider $(48.8 \%)$, friend or family support $(43,8 \%)$, access to healthcare services $(42.6 \%)$ and the ability to understand health information (30\%). The barriers of chronic pain self-management included fear of pain exacerbation $(25.3 \%)$, pain intensity $(23.2 \%)$ and depression or feeling down $(15.9 \%)$.

In two articles subjects with chronic pain listed the most supportive health care provider in supporting chronic pain self-management (Dures et al., 2016a, p.1; Lukewich et al., 2015, p. 2551). The most supportive healthcare professional in supporting chronic pain selfmanagement was the family doctor $(43.8 \%)$ followed by the physiotherapist and occupational therapist (10.5\%) (Lukewich et al., 2015, p. 2557). On the other hand, the preferred provider of psychological support during a self-management programme is the rheumatology nurse (74 $\%$ ) or doctor (55\%) and the general practitioner (51\%). Other preferred sources include family (49\%), friends (35\%), other patients (37\%), patient support group (33\%), online information (31\%), psychologist (29\%) and occupational therapist (27\%) (Dures, Hewlett, et al., 2016, p. 2). In the study conducted by Matthias and colleagues (2012) patients identified the nurse care 
manager, who administered the intervention, as being integral to patients' ability to self-manage their chronic pain (Matthias et al., 2012, pp. 1-3).

\section{Group or individual approach}

Hapidou and Horst (2016) found there are several benefits of a group intervention. For many patients this is the first encounter with other patients with a similar condition. They expressed enjoyment in being able to share their own insight and concerns with others and share stories. With the group interaction, patients also learned how to better communicate with family members. There is a strong role of an interdisciplinary approach. Patients expressed some form of gratitude. Patients commented that the program had an advantage on learning about one's own condition, which has often been limited in the past. The interdisciplinary approch provided patients with a new insight on their own condition (Hapidou, Horst, 2016, pp. 5-11).

Nees and colleagues (Nees et al., 2020, pp. 3-4) performed a multidisciplinary pain management programme for patients with chronic low back pain. Surprisingly, individual physiotherapy was, on average, rated as very beneficial and was highest during treatment. The vast majority of patients were useful in group therapy with physiotherapy $(87.3 \%)$ and with individual physiotherapy $(85.5 \%)$. Group and individual based physiotherapy were, on average, rated as very beneficial. Nearly half of patients reported $(48.6 \%)$ that individual physiotherapy was extremely helpful in alleviating of chronic back pain (CBP). A similarly high percentage of patients (38.4\%) rated group-based physiotherapy as extremely beneficial.

\section{Benefits of an interdisciplinary approach}

Hapids and Horst (2016, pp. 4-5) found there is a strong role of an interdisciplinary approach. Patients expressed some form of gratitude, staff had something positive to say about them. Patients wrote that staff showed up good balance, professionalism and compassion and empathy. Patients commented on the designed program as an advantage learning about one's own condition, which has often been limited in the past due to physiological mechanism and psychosocial consequences of chronical pain. The interdisciplinary nature of the Chronic Pain Management Unit (CPMU) patients with different perspectives. The interdisciplinary nature of the CPMU provided patients a ranging perspective.

\section{What modalities do patients use in a home setting}

Blyth and colleagues (2005, p. 285) asked patients to nominate up to 5 strategies that they use to manage their pain. The self-management strategies were grouped in active and passive strategies. Passive strategies were more frequently reported to manage chronic pain, in $59.3 \%$ (Blyth et al., 2005, p. 285) and 39.2\% of adults (Lukewich et al., 2015, p. 2555). Of the passive strategies, rest was the most commonly reported $(31.5 \%)$, followed by hot/cold pack $(23.4 \%)$ and massage $(18 \%)$. Exercise was the most common active strategy to manage chronic pain, used in $25.8 \%$ of the included adults, followed by posture correction $(12.1 \%)$. Taking medication was reported in $47 \%$ of the included adults to manage chronic pain. All of the other 
strategies were reported to be used by less than $10 \%$ of the included adults (Blyth et al., 2005, p. 285).

\section{What should be included in a self-management programme}

Hapidou and Horst (2016, p. 2) note that the main emphasis is on learning self-management techniques and encouraging the use of strategies to manage unpleasant pain-related thoughts and behaviours. The main goal is to improve the patient's sense of control over their pain by providing a set of skills to better manage physical symptoms. Goal setting, active quota implementation, stress management, relaxation, career counselling and family mediation are essential components.

Similarly, Matthias and colleagues (2012, pp. 1-3) found that helping patients find what works for their pain, holding patients accountable for their pain management and motivating with providing emotional support to patients were described as proffered approaches used by the nurse who provided self-management education. The authors proposed a model of selfmanagement, in which chronic pain-self management is a complex construct, tied to the relationship between a patient and his providers.

Changing the belief in pain into a more biopsychosocial perspective required a strong therapeutic alliance, the development of physical consciousness, and the experience of managing pain. Those that were unchanged retained their biomedical beliefs. Independence has been achieved through major improvements with newly cultivated problem-solving skills, independence, less fear of pain and improved stress management. Residual fear and poor stress management meant that small improvers were easily distressed and lacked independence. Those who were so unchanged therefore continued to feel defined by their pain in maintaining a biomedical perspective (Bunzli et al., 2016, p. 3).

Dures et al. (2016b) summarized in the following sections the findings of patients with inflammatory arthritis on interactions that facilitate participation in consultation and selfmanagement:

- patients and clinicians treat care as usual, patients and clinicians actively participate and agree,

- clinicians understand patients 'needs, understand the challenges faced by patients, assess the impact of problems and focus on patients' priorities,

- clinicians use an open mode of communication, including the use of non-didactive patient-centred approaches,

- active participation of the clinicians and the patient in consultations, including greater confidence in dealing with the problems and greater acceptability of the long-term situation (Dures et al., 2016b, pp. 3-5). 


\section{Patients expectations}

In the study by Franklin and colleagues (2016), with patient interviews were used to identify key factors influencing an individual's experience of managing chronic pain. Participants expressed a desire to understand their position and learn about self-management strategies that enable them to better manage. Because patients have benefited from participating in the management process, discussions about treatment options can improve management and rehabilitation. It was important that participants understood their condition because this changed the outcome of treatment expectations (Franklin et al., 2016, pp. 1-6).

Dures et al. (2016b) examined patient preferences and psychological support. Only $23 \%$ routinely reported regular social and emotional consultations with a rheumatologist, and $46 \%$ wanted opportunities to discuss the psychological impact. Patients want support in managing the effects of pain and fatigue ( $82 \%$ ), emotion management (57\%), work and leisure (52\%), relationships (37\%) and depression (34\%) Only $6 \%$ of patients said that social and emotional issues are not important (Dures et al., 2016b, p. 3).

Dures research (2016a) confirmed the great need of patients for psychological support. Patients want support in managing the impact and attitude to symptoms such as pain and fatigue, emotions and work and leisure. Patients showed a preference for face-to-face psychological support and providing psychological support through computer-assisted interventions. For certain groups (e.g., patients from a remote location) or specific problems (e.g., selfmanagement), online support is very appropriate. Half of the patients wanted a form of support that would be available 6 months after diagnosis. Influencing factors that include interpersonal relationships, personality traits, cognitive variables, and coping procedures could be addressed through types of services that include self-management and pain treatment programs (Dures et al., 2016a, p. 5).

\section{Discussion}

Chronic musculoskeletal pain is not in itself life-threatening, but it does significantly affect an individual's quality of life. Prolonged absence of diagnosis and effective pain management strategies can lead to life changes that condition emotional and social change. Understanding the patient's condition is a step towards improving communication between patients and the clinic. Addressing the factors from the patient's perspective helps to develop a more critical discussion of treatment options and gives him a greater sense of control and satisfaction. Previous research has found that having a diagnosis for their pain is important for individuals as it gives them a feeling of legitimacy for their pain (Franklin et al., 2016, p. 7).

One of the factors showing the promising results reported by patients is pain education. However, the patient's opinion of pain education and its impact remains relatively unknown. A cross-sectional study (Mittinty et al., 2018, pp. 1-9) involving individuals with chronic pain examined their views on pain education; whether this changed their understanding of their pain and self-management, and whether it affected their perceived pain intensity and recovery. The 
results showed that individuals who observed changes in cognitive pain and self-management when receiving pain reported lower pain intensity and higher expectations for recovery than their counterparts who did not perceive any changes in pain perception and self-management. We note that patient education should not only focus on illness and treatment, but should also include a range of flexible skills such as general issues, health system management, patient pathways, joint decision-making, multidisciplinary team assistance, patient education interest and recommended physical activity. Similar recommendations were proposed in a study by Beauvais and colleagues (2019, p. 754).

Facilitating effective self-management includes supporting patients to adjust to the many consequences of illness, which may include symptoms of disability, insecurity, loss of independence, fear and depression, anger, loneliness, sleep disturbances, and stress. Patients are looking for answers to the question of who is best suited to provide support services and assistance. An important place in the provision of these services is played by a multidisciplinary group because it understands the disease and the course of treatment. The team plays a key therapeutic role as it helps patients increase their sense of control and improve their mental well-being (Dures et al., 2016a, pp. 4-5).

The exclusive use of passive strategies was four times more common than the exclusive use of active strategies. Self-management strategies were strong associated with pain, impairment, and use health services in multiple logistic regression models. Consistent use of passive strategies was associated with an increased likelihood of an increase disability-related pain levels and more pain-related health care; the use of active strategies was associated with a reduced likelihood of also having a high level of pain disability (Blyth et al., 2005, p. 290).

The findings highlight the role of therapists as mentors in equipping patients with the knowledge and skills needed for self-management. Therapists have to challenge old beliefs, stimulate discussion, and resolve cognitive dissonance, but do so in a motivational, empathetic way. Learning from personal experience played an important role in self-management process. The visibility of patients who show insecurity in their own abilities or are at risk of prolonged stress or anxiety may highlight those who will struggle with independent self-management. The therapist's role in these situations may include raising awareness of their impact on the pain experience, further referral for multidisciplinary care, contact maintenance and follow-up when it is necessary (Bunzli et al., 2016, pp. 30-31).

From our search of the literature, we can conclude that the poorly researched area of data is precisely the population living in the community, coping with the symptoms of chronic pain, what kind of help they seek or not. It is indicated, that the use of active strategies would be related with a lower degree of disability, less distress, less reliance on medicines and less use of formal health care. Patients with chronic pain used a wide range of self-management strategies that often bring together those that are considered to be active chronic pain with passive. Strategies used and the frequency of their use was consistent with those found in others 
studies (Grimby-Ekman, Andersson, \& Hagberg, 2009, pp. 1-11, Vlaeyen, Kole-Snijders, Boeren, \& van Eek, 1995, pp. 363-372).

Research has shown the usefulness of self-management strategies for patients with chronic musculoskeletal pain. Active self-management strategies are associated with lower levels painrelated disability and use of health care. It is advisable to pay more attention to community strategies, improve awareness and acceptance of active self-management in chronic pain.

\section{Conclusion}

We set out to determine what self-management tools are deemed effective, how a selfmanagement educational programme should be constructed and which health care providers play a significant role from the patients' perspective and to compare if proposed selfmanagement interventions are consistent with the patient's perspectives. Self-management of chronic pain is transferred from the community to the individual - the user of health services, where is an important aspect cooperation between the health worker and the patient. Research shows that patients who were actively involved in treatment procedures had better management and rehabilitation options. As many researchers note, it is important to continue to explore factors relevant to individuals with musculoskeletal pain in order to find an effective, evidencebased framework for understanding and managing this condition.

Treatment or treating of chronic pain should be considered as normal care, where the patient should be actively involved. The clinician must understand and be sympathetic to the patient's needs, his challenges, and his priorities. An open, patient-centered way of communicating provides greater confidence in problem solving and greater acceptability in solving long-term situations.

There are several limitations of this review. This is not a systematic review, no risk of bias assessment was conducted. There is also a possibility that not all available studies were included in the review. Future research should focus on specific forms of interdisciplinary approaches and finding what elements of self-management are effective and what patients actually use in a home setting regularly. There is a lack of high-quality studies examining patients' perspectives of self-management of chronic pain.

We can conclude that patients need to be included in the management of their pain and be able to openly communicate with the health care provider. We believe that a multidisciplinary, group approach is best as the patients learn different self-management techniques and have several different options to find what works for them and the management of their chronic pain. With a group approach, patients meet other people with the same or similar condition and may find a support system for each other and communication between them they can exchange taughts and experiences in the management of their condition. 


\section{References}

1. Barlow, J., Wright, C., Sheasby, J., Turner, A., \& Hainsworth, J. (2002). Self-management approaches for people with chronic conditions: A review. Patient Education and Counseling. https://doi.org/10.1016/S0738-3991(02)00032-0

2. Beauvais, C., Rodère, M., Pereira, B., Legoupil, N., Piperno, M., Pallot Prades, B., ... Gossec, L. (2019). Essential knowledge for patients with rheumatoid arthritis or spondyloarthritis: Results of a multicentric survey in France among health professionals and patients. Joint Bone Spine. https://doi.org/10.1016/j.jbspin.2019.06.006

3. Blyth, F. M., March, L. M., Nicholas, M. K., \& Cousins, M. J. (2005). Self-management of chronic pain: A population-based study. Pain. https://doi.org/10.1016/j.pain.2004.12.004

4. Bunzli, S., McEvoy, S., Dankaerts, W., O’Sullivan, P., \& O’Sullivan, K. (2016). Patient Perspectives on Participation in Cognitive Functional Therapy for Chronic Low Back Pain. Physical Therapy. https://doi.org/10.2522/ptj.20140570

5. Cronin, P., Ryan, F., \& Coughlan, M. (2008). Undertaking a literature review: a step-by-step approach. British Journal of Nursing (Mark Allen Publishing). https://doi.org/10.12968/bjon.2008.17.1.28059

6. Dures, E., Almeida, C., Caesley, J., Peterson, A., Ambler, N., Morris, M., ... Hewlett, S. (2016a). Patient preferences for psychological support in inflammatory arthritis: A multicentre survey. Annals of the Rheumatic Diseases, 75(1), 142-147. https://doi.org/10.1136/annrheumdis-2014205636

7. Dures, E., Hewlett, S., Ambler, N., Jenkins, R., Clarke, J., \& Gooberman-Hill, R. (2016b). A qualitative study of patients' perspectives on collaboration to support self-management in routine rheumatology consultations. BMC Musculoskeletal Disorders. https://doi.org/10.1186/s12891016-0984-0

8. Elliott, A. M., Smith, B. H., Hannaford, P. C., Smith, W. C., \& Chambers, W. A. (2002). The course of chronic pain in the community: Results of a 4-year follow-up study. Pain. https://doi.org/10.1016/S0304-3959(02)00138-0

9. Epping-Jordan, J. A., Bengoa, R., Kawar, R., \& Sabaté, E. (2001). The challenge of chronic conditions: WHO responds. British Medical Journal. https://doi.org/10.1136/bmj.323.7319.947

10. Franklin, Z. C., Smith, N. C., \& Fowler, N. E. (2016). A qualitative investigation of factors that matter to individuals in the pain management process. Disability and Rehabilitation. https://doi.org/10.3109/09638288.2015.1107782

11. Grimby-Ekman, A., Andersson, E. M., \& Hagberg, M. (2009). Analyzing musculoskeletal neck pain, measured as present pain and periods of pain, with three different regression models: A cohort study. BMC Musculoskeletal Disorders. https://doi.org/10.1186/1471-2474-10-73

12. Hapidou, E. G., \& Horst, E. (2016). Learning to Manage Chronic Pain: The Patients' Perspective. Pain and Therapy. https://doi.org/10.1007/s40122-016-0047-0

13. Hong, J., Reed, C., Novick, D., \& Happich, M. (2013). Costs associated with treatment of chronic low back pain: An analysis of the UK general practice research database. Spine. https://doi.org/10.1097/BRS.0b013e318276450f

14. Kawi, J. (2012). Self-Management Support in Chronic Illness Care: A concept analysis. Research and Theory for Nursing Practice. https://doi.org/10.1891/1541-6577.26.2.108

15. Lukewich, J., Mann, E., Vandenkerkhof, E., \& Tranmer, J. (2015). Self-management support for chronic pain in primary care: A cross-sectional study of patient experiences and nursing roles. Journal of Advanced Nursing. https://doi.org/10.1111/jan.12717

16. Mittinty, M. M., Vanlint, S., Stocks, N., Mittinty, M. N., \& Moseley, G. L. (2018). Exploring effect of pain education on chronic pain patients' expectation of recovery and pain intensity. Scandinavian Journal of Pain. https://doi.org/10.1515/sjpain-2018-0023

17. Nees, T. A., Riewe, E., Waschke, D., Schiltenwolf, M., Neubauer, E., \& Wang, H. (2020). Multidisciplinary Pain Management of Chronic Back Pain: Helpful Treatments from the Patients' Perspective. Journal of Clinical Medicine. https://doi.org/10.3390/jcm9010145

18. Nicholas, M. K., \& Blyth, F. M. (2016). Are self-management strategies effective in chronic pain treatment? Pain Management. https://doi.org/10.2217/pmt.15.57 
19. Vlaeyen, J. W. S., Kole-Snijders, A. M. J., Boeren, R. G. B., \& van Eek, H. (1995). Fear of movement/(re)injury in chronic low back pain and its relation to behavioral performance. Pain. https://doi.org/10.1016/0304-3959(94)00279-N

$* * *$

Barbka Huzjan is a doctoral student at the Faculty of Organizational Studies in Novo mesto and employed as an occupational therapist at the Internal Clinic of the University Medical Center Ljubljana.

Ivana Hrvatin is a master's degree student at the Faculty of health sciences of the University of Ljubljana.

\section{Povzetek: \\ Stališče bolnikov do samoupravljanja kronične mišično-skeletne bolečine}

Raziskovalno vprašanje (RV): Kronična mišično-skeletna bolečina je zapleteno stanje in ena od najpogostejših vzrokov obolevnosti sodobnega časa. Samoupravljanje (ang. self-management) se nanaša na posameznikovo sposobnost obvladovanja simptomov, zdravljenja, fizičnih in psihosocialnih posledic ter sprememb življenjskega sloga, ki so značilne za življenje s kroničnim obolenjem. Raziskovalno vprašanje je; kakšno je stališče na samoupravljanje kronične mišičnoskeletne bolečine $\mathrm{z}$ vidika pacienta?

Namen: Namen pregleda literature je bil pregled izvirnih člankov, ki so poročali o samoupravnih izobraževalnih programih s stališča bolnika.

Metoda: Uporabili smo integrativni pregled literature. Iskanje je potekalo od novembra 2019 do marca 2020 v bazah PubMed, PEDro in OTseeker. Vključili smo izvirne študije, napisane v angleščini, ki so preučile bolnikov pogled na samoupravljanje. Vključene študije so bile izvedene na odraslih bolnikih obeh spolov s kronično bolečino, ki so bili poučeni o samoupravljanju bolečine. Dva avtorja sta samostojno iskala izvirne študije.

Rezultati: V pregled je bilo vključenih devet člankov. Večina študij je vključevala multidisciplinarni pristop. Bolniki so poročali, da pogosteje uporabljajo pasivne strategije za obvladovanje svoje bolečine. Želijo si aktivne vključenosti v upravljanje in sposobni komuniciranja z izvajalcem (zdravstvenih storitev) samoupravljanja. Multidisciplinarni in skupinski pristopi imajo več pozitivnih vplivov.

Organizacija: Izvajalci zdravstvenih storitev lahko posameznika spodbudijo $\mathrm{k}$ proaktivnemu vedenju $\mathrm{z}$ rednimi komunikacijskimi procesi, partnerstvom in oblikovanjem ustreznih načrtov samoupravljanja s časom.

Družba: Predvidevamo, da bo analiza pomagala prepoznati družbeno odgovornost posameznika in družbe v skupni skrbi za zdravje prebivalstva in posameznika znotraj njega.

Originalnost: Raziskava ponuja posodobljen, nov pregled na bolnikovo stališča do samoupravljanja kronične bolečine. Pregled je lahko v pomoč izvajalcem zdravstvenih storitev, saj lahko primerjajo svoja pričakovanja $\mathrm{z}$ bolnikovimi.

Omejitve/nadaljnje raziskovanje: Nadaljnje raziskave bi se morale osredotočiti na visokokakovostne študije in posebne oblike multidisciplinarnega pristopa ter raziskati, kaj bolniki izvajajo $\mathrm{v}$ domačem okolju in kako jim pomagati pri nadaljnjem samostojnem obvladovanju kronične bolečine. Omejitve tega pregleda vključujejo pomanjkanje ocene pristranskosti in dejstvo, da pregled ni sistematičen.

Ključne besede: kronična bolečina, mišično-skeletna bolečina, samoupravljanje, stališče bolnika, bolnikove izkušnje.

Copyright (c) Barbka HUZJAN, Ivana HRVATIN

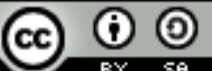

Creative Commons License

This work is licensed under a Creative Commons Attribution-ShareAlike 4.0 International License. 